\title{
Is gestational diabetes a risk factor for neonatal hearing loss?
}

\author{
Gestasyonel diyabet yenidoğan işitme kaybında bir risk faktörü müdür?
}

Fatih Mehmet Hanege $^{1}$, Burcu Yılmaz Hanege ${ }^{2}$, Serdal Çelik ${ }^{1}$, Ahmet Göçmen ${ }^{2}$, M. Tayyar Kalcıoğlu ${ }^{1}$

\begin{abstract}
Aim: Newborn hearing screening is important for early detection of hearing loss in newborns. Gestational diabetes is a metabolic disease that can occur in pregnancy and cause complications such as those in the other diabetes mellitus patients. As uncomplicated gestational diabetes has not been described as a cause for prenatal complications in the literature, this study aimed to determine whether gestational diabetes is a risk factor for hearing impairment among newborns.

Methods: This retrospective study included infants born between 2015 and 2017. The infants were divided into two groups: Control group consisted of 100 randomly selected children of healthy mothers. Study group consisted of 79 infants whose mothers had gestational diabetes mellitus. Exclusion criteria included other risk factors and 8 infants were excluded from the study due to risk factors other than gestational diabetes mellitus. The results of transient evoked otoacoustic emissions in infants of mothers with gestational diabetes were compared with those of infants of healthy mothers.

Results: In this study, we compared transient evoked otoacoustic emission results of 71 infants of gestational diabetic mothers with 100 infants of healthy mothers. All the infants of healthy mothers, as well as the infants of mothers with gestational diabetes without risk factors, passed the transient evoked otoacoustic emission test. Conclusions: There was no difference detected in the hearing screening results between infants of mothers with gestational diabetes and infants of healthy mothers.
\end{abstract}

Keywords: Gestational diabetes, neonatal hearing loss, hearing screening, otoacoustic emission

Öz

Amaç: İșitme kaybı, yenidoğanlar arasında en sık görülen konjenital anomalilerden biridir. Yenidoğan işitme tarama programı işitme kaybı olan yenidoğanlarda erken tanı için önem arz etmektedir Gestasyonel diyabet ise gebelikte ortaya çıkan ve diğer diyabetes mellitus tanısı alan hastalardaki gibi komplikasyonlara neden olabilen metabolik bir hastalıktır. Komplike olmamış gestasyonel diyabeti işitme kaybı riski oluşturan prenatal bir komplikasyon olarak tanımlayan bir çalışma literatürde bulunmamaktadır. Bu çalışmada gestasyonel diyabetin yenidoğanlarda işitme bozukluğu için bir risk faktörü olup olmadığını belirlemeyi amaçladık.

Metod: Bu retrospektif çalışmaya 2015-2017 yılları arasında doğan bebekler dahil edildi. Bebekler iki gruba ayrıld; Kontrol grubu: Rastgele seçilen sağlıklı 100 annenin çocuğundan oluşuyordu. Çalışma grubu: 8 tanesi en az bir risk faktörüne sahip olup çalışma dışında bırakılan, gestasyonel diyabeti olan annelerden doğan 79 bebekten oluşan grup idi. Gestasyonel diyabeti olan annelerden doğan bebeklerin transient otoakustik emisyon sonuçlarının sağlıklı annelerden doğanların sonuçları ile karşılaştırdık.

Bulgular: Bu çalışmada 71 gestasyonel diyabeti olan anne bebeği ile 100 sağlıklı anne bebeğinin transient otoakustik emisyon sonuçları ile karşılaştırıldı. Sağlıklı annelerin bebeklerinin yanı sıra risk faktörü olmayan gestasyonel diyabeti olan anne bebeklerinin tümü transient otoakustik emisyon testini geçti.

Sonuç: Annesinde gestasyonel diyabeti olan bebeklerin işitme tarama sonuçları ile annesi sağlıklı olan bebeklerin işitme tarama sonuçları arasında bir fark tespit edilememiştir.

Anahtar Kelimeler: Gestasyonel diyabet , yenidoğan işitme kaybı, işitme taraması, otoakustik emisyon
1 Istanbul Medeniyet University Faculty of Medicine, Department of Otorhinolaryngology, Istanbul, Turkey.

2 Istanbul Medeniyet University Faculty of Medicine, Department of Obstetrics and Gynecology, Istanbul, Turkey.

Ethics Committee Approval: The study wass approved by the local ethical authority.

Etik Kurul Onayı: Çalışma lokal etik komite tarafindan onaylanmıştır.

Conflict of Interest: No conflict of interest was declared by the authors.

Çıkar Çatışması: Yazarlar çıkar çatışması bildirmemişlerdir.

Financial Disclosure: The authors declared that this study has received no financial support. Finansal Destek: Yazarlar bu çalışma için finansal destek almadıklarını beyan etmişlerdir.

Gelis Tarihi / Received: 02.12.2018

Kabul Tarihi / Accepted: 13.02.2019

Yayın Tarihi / Published: 15.03.2019

This study was presented at the $40^{\text {th }}$ Turkish National Otorhinolaryngology-Head and Neck Surgery Congress, 7-11 November, 2018, Antalya, Turkey. Bu çalışma 7-11 Kasım 2018'de Antalya, Türkiye'de düzenlenen 40. Ulusal Otorinolaringoloji-Baş ve Boyun Cerrahisi Kongresi’nde sunulmuştur.

Sorumlu yazar / Corresponding author:

Fatih Mehmet Hanege

Adres/Address:

Dr. Erkin Cad. Goztepe, Kadikoy, Istanbul, Turkey.

e-posta: hanege@hotmail.com

Tel/Phone: (+90) 2165664000

Copyright $\odot$ ACEM 


\section{Introduction}

Hearing loss is one of the most common congenital anomalies among newborns. The incidence of impairment of bilateral congenital hearing is 1.4 per 1000 births [1]. Early diagnosis and treatment is important for the development of hearing systems and for the preservation of the cognitive functions in newborns. Normal hearing capacity in early infancy is very important for social, emotional and mental development as well as speech and language development in children.

The Joint Committee on Infant Hearing has been focusing on the importance of newborn hearing screening (NHS) for a long time [2]. In 1978, Kemp applied transient evoked otoacoustic emissions (TEOAE) to assess the hearing status of newborns [3]. After some preliminary studies on neonatal hearing screening, it was suggested that these tests could be used for diagnosing premature hearing loss in newborns [4]. NHS is highly functional in early diagnosis and was approved as a national program originally in the United Kingdom and the United States and subsequently in Europe, and was starting to be performed on all newborns in some countries [5-9].

Early diagnosis and treatment can prevent the negative consequences of hearing loss. TEOAE and auditory brainstem response $(\mathrm{ABR})$ are known to be suitable and usable basic tools for NHS [10]. If a newborn does not have a risk factor such as prenatal and neonatal infection, immaturity, asphyxia, ototoxic drug use, and hyperbilirubinemia, the first choice for NHS is TEOAE. The above mentioned factors are defined as risk factors for neonatal hearing impairment [11]. Newborns with one of these risk factors and those who failed the TEOAE in one or two ears directly refer to ABR test.

Gestational diabetes is a pathological condition that occurs in the second and third trimesters in mothers who have no previous history of diabetes. Diabetes mellitus is a metabolic disorder that also has a genetic predisposition to complete or partial impairment of insulin function. Metabolic changes manifest clinically with vascular or neuropathic complications. Gestational diabetes is a metabolic disease that can occur during pregnancy and cause complications such as those in other diabetes mellitus patients. The main aim of the treatment of gestational diabetes mellitus is prevention of complications. Although diabetes mellitus often results in hearing impairment, there is little data showing whether gestational diabetes is an antenatal risk factor for cochlear damage and hearing loss [12].

In this study, we aimed to determine whether there is a risk factor for hearing impairment in neonates from mothers with gestational diabetes. We compared the TEOAE outcomes of infants from mothers with gestational diabetes with those from healthy mothers.

\section{Material and methods}

This study began after receiving permission from the local ethics committee (\# 11 ${ }^{\text {th }}$ February, 2014; 2014/0031). This study was conducted in accordance with the principles of the Declaration of Helsinki.

This retrospective case-control study involved infants born between January 2015 and January 2017 in Istanbul Medeniyet University Goztepe training and research hospital. The infants were divided into two groups. The control group consisted of 100 randomly selected children from healthy mothers. These mothers were those who did not have diseases such as gestational hypertension, gestational diabetes, preeclampsia, threatened preterm labor and those who did not have a history of additional drug use. 100 term newborns who have not experienced any complications during and after birth were included in the study as the control group. Study group consist of 79 infants whose mothers had gestational diabetes mellitus .Exclusion criteria included other risk factors such as craniofacial anomalies, low birth weight $(<1500 \mathrm{gr})$, meningitis, ototoxic drug use, hyperbilirubinemia, low Apgar score, intrauterine infections, family history of hearing loss, presence of any syndrome related to congenital hearing loss and 8 infants were excluded from the study due to risk factors other than gestational diabetes mellitus. The study was performed with the remaining 71 patients. In this study, screening tests (TEOAE) were performed using a Madsen Accuscreen otoacustic emission scanner (Madsen Accuscreen Pro handheld, GN Otometrics, Denmark), which emits a series of clicks ranging from $35 \mathrm{~dB}$ to $65 \mathrm{~dB}$. In cases when the infant fails the test, the scan is repeated at 15 and 30 days. Infants, who did not pass the test on 30th day, were evaluated with ABR. Infants with risk factors were screened directly with ABR. All screening tests were performed by the same audiometrist with the infants sleeping in a quiet room.

Informed Consent: Written informed consent was obtained from the patients' parents.

\section{Statistical analysis}

To describe categorical variables frequencies and percentages was used. First, the $15^{\text {th }}$ day and the $30^{\text {th }}$ day TEOAE rates between neonates of healthy mothers and neonates of gestational diabetic mothers were evaluated by using Fisher Exact test. The critical value for statistical significance was set at 0.05 . Statistical calculations were performed by IBM Corp. Released 2017. IBM SPSS Statistics for Windows, Version 25.0. Armonk, NY: IBM Corp

\section{Results}

The mean age of the mothers in control and study groups was 30.29 years (range: 19-47) and 29.30 years (range: 19-45), respectively. Four of 71 infants could not pass the first TEOAE test on day 5. Two of these were administered the test on the 15th day; two infants who did not pass the first two tests passed the screening on the $30^{\text {th }}$ day. Five out of 100 infants from randomly selected healthy mothers were not able to pass the $5^{\text {th }}$ day TEOAE. Of the remaining five infants, three went through the $15^{\text {th }}$ day scan and two were administered TEOAE on the $30^{\text {th }}$ day and two infants who did not pass the first two tests passed the screening on the $30^{\text {th }}$ day. ABR test was performed to four babies in total who failed TEOAE from both groups. All those babies passed the ABR test.

There was no significant difference in the rate of failure on the $5^{\text {th }}$ day TEOAE test between infants from gestational diabetic mothers $(5.6 \%)$ and infants from healthy mothers $(5 \%)$ $(\mathrm{p}=1.000, \mathrm{p}>0.05)$.

There was no significant difference in the rate of failure on the $15^{\text {th }}$ day TEOAE test between infants from gestational diabetic mothers $(50 \%)$ and of those from healthy mothers $(40 \%)$ $(\mathrm{p}=1.000, \mathrm{p}>0.05)$.

There was no significant difference in the rate of failure on the $30^{\text {th }}$ day TEOAE between infants from gestational diabetic mothers who failed on second TEOAE test (100\%) and infants from healthy mothers who failed on 30th day TEOAE test (100\%) $(\mathrm{p}=1.000, \mathrm{p}>0.05)$ (Table). 


\section{Discussion}

The inner ear is very sensitive to ischemic and immunological damage, and vascular occlusion can cause hearing loss $[13,14]$. Therefore, gestational diabetes can theoretically damage the inner ear and cause sensorineural hearing loss in both mother and newborn due to microcirculation and the effects on possible immunological pathogenesis. If the mother is affected, it is reasonable to think that the fetus, the newborn, is also affected.

Table. TEOAE results of neonates born from healthy and diabetic mothers.

\begin{tabular}{lccccc} 
& \multicolumn{2}{c}{$\begin{array}{c}\text { Neonates of healthy } \\
\text { mothers }\end{array}$} & \multicolumn{2}{c}{$\begin{array}{c}\text { Neonates of diabetic } \\
\text { mothers }\end{array}$} & P \\
\hline $\begin{array}{l}\mathrm{N}(\%) \\
\text { TEOAE on } 5^{\text {th }}\end{array}$ day & Failed & Total & Failed & Total & \\
$\begin{array}{l}\text { after the birth } \\
\text { TEOAE on } 15^{\text {th }} \text { day }\end{array}$ & $5(5)$ & $100(100)$ & $4(5.6)$ & $71(100)$ & 1.00 \\
$\begin{array}{l}\text { after the birth } \\
\text { TEOAE on } 30^{\text {th }}\end{array}$ & $2(40)$ & $5(100)$ & $2(50)$ & $4(100)$ & 1.00 \\
after the birth & $2(100)$ & $2(100)$ & $2(100)$ & $2(100)$ & 1.00 \\
\hline
\end{tabular}

TEOAE: Transient evoked otoacoustic emissions

There are limited studies on hearing loss in newborns from gestational diabetic mothers. In addition, the results of current studies are contradictory. When we focus on studies of hearing loss from mothers with gestational diabetes, we notice different results. In a study by Ewart-Toland et al. [15], nine of 27 children from diabetic mothers with craniofacial anomalies were found to have hearing loss. Mixed or sensorineural hearing loss was detected in 4 of these infants, while transmission type hearing loss was detected in 2 and unrecognized hearing loss in the remaining 3 infants [15]. In our study, no hearing loss was detected in any of the 71 babies born from the diabetic mothers.

Gratz et al. [16] reported two cases of gestational diabetes mellitus presenting with hypoplasia ipsilateral facial paralysis and ipsilateral deafness. Kelemen evaluated the results of histopathological analysis of specimens collected from a woman with severe gestational diabetes whose pregnancy was terminated during the second trimester. In this evaluation, it was determined that temporal bone development was normal, but there were bleeding spots on the cochlea and vestibulocochlear nerve [17]. None of the babies born from the mothers having gestational diabetes who were included in the study had any additional complication.

The most important complications of gestational diabetes are prematurity and abnormal birth weight. Many studies in the literature have found that gestational diabetes was a risk factor for premature labor, and macrosomia (> $4000 \mathrm{~g}$ ) rates were high despite premature labor [18-20]. There is no study in the literature about neonatal hearing evaluation of diabetic pregnant women who had delivered without any complication. When we evaluated the results, we found no significant difference between screening tests of infants of mothers with gestational diabetes born after 35 th week and infants from healthy mothers.

However, several limitations exist in our study. As our study was conducted retrospectively, ABR test results were not used in our study because the newborn hearing screening was performed by using TOAE before 2017. According to the national newborn hearing screening program, ABR test was performed to all newborns either having a risk factor or not since 2017. Currently, the usage of ABR test in studies that will be performed will give a clearer insight about the effect of gestational diabetes on neonatal hearing.

As an overall conclusion, gestational diabetes mellitus was not found to be a risk factor for congenital hearing loss in infants born to mothers with gestational diabetes without any complication.

\section{References}

1. Turchetta R, Conti G, Marsella P, Orlando MP, Picciotti PM, Frezza S, et al. Universal newborn hearing screening in the Lazio region, Italy. Ital J Pediatr. 2018;44:104.

2. Committee on Fetus and Newborn. Joint statement on neonatal screening for hearing impairment.Pediatrics. 1971;47:1085.

3. Kemp DT. Stimulated acoustic emissions from within the human auditory system. J Acoust Soc Am. 1978;64:138691.

4. National Institutes of Health Consensus Development Conference Statement. Early identification of hearing impairment in infants and young children. Int J Pediatr Otorhinolaryngol. 1993;27:215-27.

5. Wood SA, Sutton GJ, Davis AC. Performance and characteristics of the Newborn Hearing Screening Programme in England: The first seven years. Int $\mathbf{J}$ Audiol. 2015;54:353-8.

6. Chung W, Beauchaine KL, Grimes A, O'Hollearn T, Mason C, Ringwalt S. Reporting Newborn Audiologic Results to State EHDI Programs. Ear Hear. 2017;38:63842.

7. Grandori F. European Consensus Statement on Neonatal Hearing Screening. J Laryngol Otol. 1998;112:1219.,

8. Kemaloglu YK, Gokdogan C, Gunduz B, Onal EE, Turkyilmaz C, Atalay Y. Newborn Newborn hearing screening outcomes during the first decade of the program in a reference hospital from Turkey. Eur Arch Otorhinolaryngol. 2016;273:1143-49.

9. Jakubíková J, Kabátová Z, Pavlovcinová G, Profant M. Newborn hearing screening and strategy for early detection of hearing loss in infants. Int J Pediatr Otorhinolaryngol. 2009;73:607-12.

10. Arslan S, Işik AU, Imamoglu M, Topbas M, Aslan Y, Ural A. Universal newborn hearing screening; automated transient evoked otoacoustic emissions. B-ENT. 2013;9:122-31.

11. Meyer C, Witte J, Hildmann A, Hennecke KH, Schunck KU, Maul K. Neonatal screening for hearing disorders in infants at risk: incidence, risk factors, and follow-up. Pediatrics. 1999;104:900-4.

12. Selcuk A, Terzi H, Turkay U, Kale A, Genc S. Does gestational diabetes result in cochlear damage? J Laryngol Otol. 2014;128:961-5.

13. Woolf NK, Harris JP. Cochlear pathophysiology associated with inner ear immune responses. Acta Otolaryngol. 1986;102:353-64.

14. Hanege BY, Hanege FM, Kalcioglu MT, Gocmen A. Is maternal preeclampsia risk factor for neonatal hearing loss? B-ENT. 2017;13:219-23.

15. Ewart-Toland A, Yankowitz J, Winder A, Imagire R, Cox VA, Aylsworth AS. Oculoauriculovertebral abnormalities in children of diabetic mothers. Am J Med Genet. 2000;90:303-9.

16. Gratz ES, Pollack MA, Zimmerman RD. Congenital facial palsy and ipsilateral deafness: association with maternal diabetes mellitus. Int J Pediatr Otorhinolaryngol. 1981;3:335-41.

17. Kelemen G. Aural changes in the embryo of diabetic mother. AMA Arch Otolaryngol. 1955;62:357-69.

18. Sudasinghe BH, Wijeyaratne CN, Ginige PS. Long and short-term outcomes of Gestational Diabetes Mellitus (GDM) among South Asian women - A community-based study. Diabetes Res Clin Pract. 2018;145:93-101.

19. Schwartz R, Teramo KA. Effects of diabetic pregnancy on the fetus and newborn. Semin Perinatol. 2000;24:120-35. 
20. Weintrob N, Karp M, Hod M. Short- and long-range complications in offspring of diabetic mothers. J Diabetes Complications. 1996;10:294-301. 